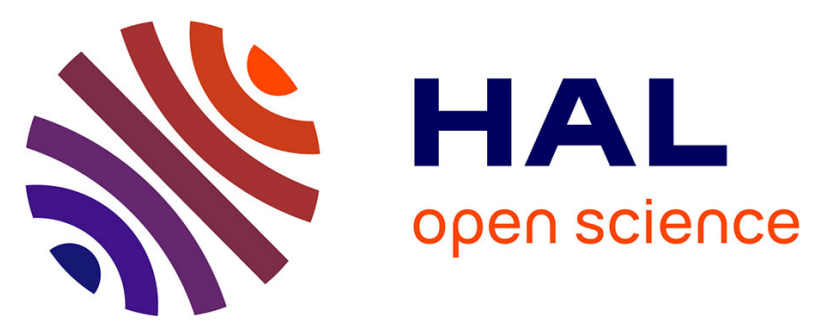

\title{
Thunderstorms in Corsica Island measured during the EXAEDRE aircraft campaign
}

Keun-Ok Lee, Eric Defer, Pauline Combarnous, Jean-Pierre Pinty, Magalie

Buguet, Olivier Caumont, Julien Delanoë, Louis Jaffeux, Stéphane Pedeboy, Serge Prieur, et al.

\section{To cite this version:}

Keun-Ok Lee, Eric Defer, Pauline Combarnous, Jean-Pierre Pinty, Magalie Buguet, et al.. Thunderstorms in Corsica Island measured during the EXAEDRE aircraft campaign. vEGU21, Apr 2021, Virtual Meeting, Austria. hal-03318943

\section{HAL Id: hal-03318943 \\ https://hal.univ-reunion.fr/hal-03318943}

Submitted on 11 Aug 2021

HAL is a multi-disciplinary open access archive for the deposit and dissemination of scientific research documents, whether they are published or not. The documents may come from teaching and research institutions in France or abroad, or from public or private research centers.
L'archive ouverte pluridisciplinaire HAL, est destinée au dépôt et à la diffusion de documents scientifiques de niveau recherche, publiés ou non, émanant des établissements d'enseignement et de recherche français ou étrangers, des laboratoires publics ou privés. 


\title{
Thunderstorms in Corsica Island measured during the EXAEDRE aircraft campaign
}

\author{
Keun-Ok Lee*1, ${ }^{2}$, Eric Defer ${ }^{1}$, Pauline Combarnous ${ }^{1,3}$, Jean-Pierre Pinty ${ }^{1}$, Magalie Buguet ${ }^{4}$, \\ Olivier Caumont ${ }^{3}$, Julien Delanoë ${ }^{5}$, Louis Jaffeux ${ }^{6}$, Stéphane Pedeboy ${ }^{7}$, Serge Prieur ${ }^{1}$, Evelyne \\ Richard $^{1}$, and Alfons Schwarzenboeck ${ }^{6}$ \\ ${ }^{1}$ Laboratoire d'Aérologie, Université de Toulouse, CNRS, UPS, Toulouse, France \\ ${ }^{2}$ Laboratoire de l'Atmosphère et des cyclones, UMR8105, CNRS, Météo-France, Université de la Réunion, Saint-Denis \\ de La Réunion, France \\ ${ }^{3}$ CNRM, Météo-France, Toulouse, France \\ ${ }^{4}$ ONERA, Palaiseau, France \\ ${ }^{5}$ LATMOS, Guyancourt, France \\ ${ }^{6}$ LaMP, Université Clermont Auvergne, Aubière, France \\ ${ }^{7}$ Meteorage, Pau, France \\ *email : keunok.lee@univ-reunion.fr
}

The aim of this study is to enhance our understanding about the microphysical structure of convective cloud systems and its relationships to the ambient electrical field, and to assess the capability of a model to capture the cloud electrical properties. This study relies on the EXAEDRE (EXploiting new Atmospheric Electricity Data for Research and the Environment) aircraft campaign that took place from 13 September to 8 October 2018 in Corsica Island. Eight electrified convective systems were successfully sampled during the campaign by the French Falcon 20 aircraft (e.g. RASTA Doppler cloud radar, microphysics probes, electric field mills) and ground-based platforms (Lightning Mapping Array network, Météorage operational lightning locating system and Météo-France weather radars). In this study, a multi-cell thunderstorm which developed over the complex topography of Corsica Island on 17 September 2018 was selected to investigate and to understand the physical processes linking lightning occurrence, electrification efficiency, cloud microphysics and dynamics. The detailed analysis results using the unprecedented airborne and ground-based dataset and their comparison to the numerical simulation results with a horizontal grid spacing of $1 \mathrm{~km}$ comprising the explicit electrical scheme CELLS (Cloud Electrification and Lightning Scheme) implemented in the cloud resolving model Meso-NH has been conducted. The key results will be presented at the conference. 